\title{
IMPLEMENTASI TEORI BELAJAR HUMANISTIK PADA MATA KULIAH KONSEP DASAR SAINS MATERI BAGIAN TUMBUHAN DAN FUNGSINYA MAHASISWA PGMI IAIH PARE TAHUN AJARAN 2021/2022
}

\author{
Sri Putrianingsih ${ }^{1}$ \\ puputasyifa22@gmail.com \\ Irma Nur Ma' rifah ${ }^{2}$ \\ Irmanurm97@gmail.com
}

\begin{abstract}
Abstrak
Belajar adalah suatu proses yang ditempuh manusia untuk memperoleh pengetahuan, dimulai dari tidak tahu menjadi tahu. Berdasarkan pandangan teori belajar humanistik bahwa suatu proses dalam belajar itu penting, artinya siswa diberi kebebasan dalam belajar dan tidak ada paksaan dalam belajar. Berhasil tidaknya pencapaian tujuan pembelajaran sangat bergantung pada proses pembelajaran. Teori belajar humanistik sendiri merupakan teori yang memanusiakan manusia yang mengarah pada pembebasan. Oleh karena itu, belajar tidak hanya sekedar menyampaikan informasi, tetapi dengan penerapan teori humanistik, siswa mampu mengetahui dan memahami keberadaan dan potensi dirinya tanpa ditekan atau terancam.
\end{abstract}

Kata Kunci: teori belajar humanistik, konsep dasar IPA

\footnotetext{
${ }^{1}$ IAI Hasanuddin Pare

${ }^{2}$ IAI Tribakti Kediri
} 


\begin{abstract}
Learning is a process taken by humans to acquire knowledge, starting from not knowing to knowing. Based on the view of humanistic learning theory that a process in learning is important, it means that students are given freedom in learning and there is no coercion in learning. The success or failure of achieving learning objectives is highly dependent on the learning process. Humanistic learning theory itself is a theory that humanizes humans which leads to liberation. Therefore, learning is not just conveying information, but with the implementation of humanistic theory, students are able to know and understand their existence and potential without being pressured or threatened.
\end{abstract}

Keywords: humanistic learning theory, basic concepts of science

\title{
A. Pendahuluan
}

Berbicara mengenai belajar dan pembelajaran tentu tidak akan pernah berakhir sejak manusia lahir sampai akhir hayat. Belajar mewujudkan suatu kegiatan yang hidup dan mewujudkan komponen yang sangat penting dalam setiap penyelenggaraan jenis dan jenjang pendidikan. ${ }^{3}$ Belajar tidak hanya diperoleh dari lembaga formal seperti sekolah saja, melainkan kita dapat belajar melalui berbagai tempat dan berbagai media. Penyelenggaraan belajar mmapu diperoleh mulai sejak dini.

Teori belajar banyak dikaitkan dengan ruang lingkup bidang psikologi, bisa diartikan bahwa semua hal yang dibahas dalam belajar, berkaitan pula dengan keadaan manusia sebagai subjek yang mengalami, mengikuti bahkan mengembangkan diri melalui belajar. Teori belajar, turut membantu pelaksanaan pendidikan dengan menjawab atau membahas mengenai masalah yang muncul dalam belajar sehingga pelaksanaan pendidikan dapat mencapai tujuan awal sesuai dengan yang diharapakan. Hal ini dapat disimpulkan bahwa berhasil tidaknya pencapaian tujuan pembelajaran sangat bergantung pada proses pembelajaran.

Berdasarkan pandangan teori belajar humanistik, suatu proses dalam pembelajaran itu penting, artinya mahasiswa diberi kebebasan dalam belajar dan tidak ada paksaan dalam pembelajaran. Sebagaimana yang telah dikemukakan oleh Carl Rogers bahwa siswa yang belajar hendaknya tidak dipaksa, melainkan diberi

\footnotetext{
${ }^{3}$ Muhibbin Syah, Psikologi Pendidikan: Suatu Pendekatan Baru (Bandung: Remaja Rosdakarya, 1995). h. 88
} 
kebebasan, siswa diharapkan dapat mengambil kesimpulan sendiri dan berani bertanggug jawab terhadap keputusan-keputusan yang diambil. ${ }^{4}$

Teori belajar humanistik sendiri merupakan teori yang memanusiakan manusia yang berujung pada pembebasan. Siswa atau mahasiswa mendapat kebebasan dalam berekspresi dan menuangkan pemikiran dalam belajar, mahasiswa atau siswa diberi kesempatan untuk mengembangkan teori materi pelajaran yang telah diterimanya selama bangku perkuliahan, Oleh sebab itu, pembelajaran bukan sekedar penyampaian informasi, namun dengan adanya implementasi teori humanistik mahasiswa mampu mengetahui dan memahami eksistensi dan potensi yang mereka miliki. Teori humanistik mampu mengubah teori yang dimiliki mahasiswa untuk diterapkan dalam kehidupan sehari hari atau dalam kehidupan bermasyarakat.

\section{B. Pembahasan}

\section{Implementasi}

Istilah implementasi bukan lagi hal yang baru dalam dunia pendidikan, setiap pendidik setelah melakukan perancangan terhadap program ataupun rencana tentu akan berusaha sebaik mungkin untuk mewujudkan rencana tersebut agar sukses dan mencapai tujuan yang diharapkan sesuai dengan kurikulum yang berlaku.

Mengartikan bahwa implementasi sebagai "pelaksanaan atau penerapan". 5 Implementasi atau penerapan teori dalam praktikum pembelajaran mampu meningkatkan minat belajar mahasiswa, terutama dengan menggunakan teori humanistik. Hal ini berarti bahwa segala sesuatu yang dilaksanakan dan diterapkan sesuai dengan kurikulum yang telah dirancang yang kemudian dijalankan sepenuhnya sesuai dengan peraturan yang sudah ditetapkan.

Implementasi biasanya dilakukan setelah perencanaaan sudah dianggap sempurna. Jadi dapat diketahui bahwa implementasi adalah suatu tindakan atau pelaksanaan dari sebuah rencana yang sudah disusun secara matang dan terperinci.

\footnotetext{
${ }^{4}$ Eveline Siregar and Hartini Nara, Teori Belajar Dan Peembelajaran (Bogor: Ghalia Indonesia, 2011). h. 37

5 M. Joko Susilo, Kurikulum Tingkat Satuan Pendidikan (Yogyakarta: Pustaka Pelajar, 2007). h. 174
} 
Adapan tujuan implementasi sebagai berikut :

a. Tujuan utama implementasi yaitu untuk melaksanakan rencana yang telah / sudah disusun dengan cermat, baik itu oleh individu maupun kelompok.

b. Untuk dapat menguji serta juga mendokumentasikan suatu prosedur didalam penerapan rencana dan juga sebuah kebijakan.

c. Untuk dapat mewujudkan tujuan-tujuan yang akan dicapai di dalam perencanaan disertai kebijakan yang telah dirancang.

d. Untuk dapat mengetahui kemampuan masyarakat dalam menerapkan suatu kebijakan dan rencana sesuai dengan yang diinginkan.

e. Untuk dapat mengetahui tingkat keberhasilan suatu kebijakan yang telah/sudah dirancang demi peningkatan mutu.

\section{Teori Belajar Humanistik}

Teori adalah suatu pendapat yang didasarkan pada sebuah penelitian maupun penemuan yang telah didukung oleh data dan argumentasi. ${ }^{6}$ Teori merupakan perangkat prinsip-prinsip yang terorganisasi tentang peristiwaperistiwa tertentu yang berhubungan dengan lingkungan. Teori dikatakan sebagai hubungan kausalitas dari proposisi-proposisi. Teori merupakan hal yang sangat penting dan utama yang digunakan dalam proses penentuan belajar mengajar.

Belajar merupakan sebuah proses yang ditempuh manusia untuk memperoleh pengetahuan, berawal dari tidak tahu menjadi tahu. Belajar adalah suatu perubahan pada diri individu yang dapat disebabkan oleh pengalaman. Belajar terjadi dengan banyak cara, bisa terjadi dengan disengaja, seperti ketika mahasiswa memperoleh informasi yang disampaikan oleh dosen di kelas, maupun tidak disengaja seperti halnya ketika sedang berperilaku sehari-hari. ${ }^{7}$ Belajar diteri seseorang sejak dini, sampai seseorang tersebut meninggl dunia, hal itu dikarenakan belajar tidak hanya diperoleh di lembaga formal, tetapi dapat diperoleh dari berbagai sudut dan situs.

${ }^{6}$ Heppi El Rais, Kamus Ilmiah Populer (Yogyakarta: Pustaka Pelajar, 2012). h. 667
7 Sri Esti Wuryani Djiwandono, Psikologi Pendidikan (Jakarta: Grasindo, 2006). h. 120 
Belajar merupakan suatu aktivitas mental ataupun psikis yang berlangung dalam interaksi aktif dengan lingkungan yang dapat menghasilkan sejumlah perubahan dalam pengetahuan, pemahaman, keterampilan dan nilai sikap. Dan perubahan pada setiap individu itu sendiri bersifat relatif konstan dan membekas. ${ }^{8}$ Dengan demikian belajar mempengaruhi psikir seseorang atau pelajar, karena dengan belajar seorang mahasiswa akan mengalami perubahan perilaku yang lebih baik.

Belajar dapat diartikan sebagai suatu aktivitas psikis yang dilakukan oleh seseorang sehingga terjadi perubahan pola pikir dan perilaku yang diakibatkan oleh belajar tersebut. Belajar juga dapat diartikan sebagai kegiatan yang dapat mengubah struktur pengetahuan lampau hingga terbentuk struktur pengetahuan yang baru. ${ }^{9}$ Teori Belajar merupakan upaya untuk mendeskripsikan bagaimana manusia belajar, sehingga dapat membantu kita dalam memahami sebuah proses inhern yang kompleks dari belajar. Pendapat Cahyo mengenai teori belajar dapat diartikan sebagai konsep-konsep dan prinsip-prinsip belajar yang bersifat teoritis dan telah teruji kebenarannya melalui sebuah eksperimen. Ada beberapa perspektif dalam teori belajar, yaitu Behaviorisme, Kognitivisme, dan Humanistik. ${ }^{10}$

Humanistik sendiri merupakan aliran dalam psikologi yang muncul tahun 1950an. Teori belajar humanistik merupakan salah satu teori belajar yang penting dan harus dipahami oleh seorang pendidik. Hal ini untuk mewujudkan pembelajaran yang berkualitas dan sesuai dengan tuntutan pendidikan abad ke-21. Humanistik sendiri berasal dari kata "human" yang berarti manusia. Dalam arti luas humanistik sendiri adalah memandang manusia sebagai manusia, artinya menusia merupakan makhluk hidup ciptaan Tuhan dengan fitrah-fitrah tertentu. Sebagai makhluk hidup, manusia harus melangsungkan, mempertahankan, dan mengembangkan potensi-potensi yang telah dimiliki. ${ }^{11}$

\footnotetext{
${ }^{8}$ W.S Winkel, Psikologi Pengajaran (Yogyakarta: Media Abadi, 2004). h. 59

9 Agus Zaenul Fitri, Manajemen Kurikulum Pendidikan Islam (Bandung: ALVABETA cv, 2013). h. 196

10 Dra. Tutik Rachmawati, M.Pd, Teori Belajar Dan Proses Pembelajaran Yang Mendidik (Yogyakarta: GAVA MEDIA, 2015). h. 36

11 Baharuddin and Moh. Makin, Pendidikan Humanistik: Konsep, Teori Dan Aplikasi Praksis

Dalam Dunia Pendidikan (Yogyakarta: Ar-Ruzz Media, 2007). h. 22
} 
Tujuan utama para pendidik adalah membantu peserta didik untuk mengembangkan dirinya, yaitu membantu masing-masing individu untuk mengenal diri mereka sendiri sebagai manusia yang unik dan membantu dalam mewujudkan potensi-potensi yang ada dalam diri mereka. Tujuan dasar pendidikan humanistik adalah mendorong manusia menjadi pribadi yang mandiri dan independen, mengambil tanggung jawab untuk pembelajaran mereka, menjadi kreatif dan tertarik dengan seni, dan menjadi ingin tahu tentang dunia di sekitar mereka.

Berhubungan dengan hal itu, prinsip-prinsip pendidikan humanistik dapat paparkan sebagai berikut :

a. Peserta didik harus dapat memilih apa yang ingin mereka pelajari. Pendidik yang humanistik percaya bahwa peserta didik akan semangat untuk mengkaji materi bahan ajar apabila sesuai dengan kebutuhan dan keinginannya.

b. Tujuan pendidikan harus dapat mendorong keinginan peserta didik untuk belajar dan mengajari mereka tentang cara belajar. Peserta didik harus memotivasi dan merangsang diri pribadi untuk belajar sendiri.

c. Pendidik humanistik percaya bahwa nilai tidak relevan dan hanya evaluasi diri (self evaluation) yang bermakna. Kejuaraan hanya mendorong pesertadidik belajar untuk mencapai tingkat tertentu, bukan untuk kepuasan pribadi. Selain itu, pendidik humanistik menentang tes objektif, karena mereka hanya menguji kemampuan peserta didik untuk menghafal dan tidak memberi timbal balik pendidikan yang cukup kepada pendidik dan peserta didik.

d. Pendidik Humanistik percaya bahwa perasaan maupun pengetahuan sangat penting dalam proses belajar dan tidak memisahkan aspek kognitif dan afektif.

e. Pendidik Humanistik menekankan perlunya peserta didik terhindar dari tekanan lingkungan, sehingga mereka akan merasa lebih aman untuk belajar. Setelah peserta didik merasa aman, peoses belajar mereka menjadi lebih mudah dan akan lebih bermakna. ${ }^{12}$

\footnotetext{
${ }^{12}$ Makin. h. 24
} 
Sesuai dengan Teori Humanistik, tujuan belajar yaitu untuk memanusiakan manusia. Proses belajar akan berhasil apabila pelajar paham akan lingkungannya dan dirinya sendiri. Pelajar pada proses belajarnya wajib berusaha supaya lambatlaun dia sanggup mencapai aktualisasi diri dengan sebaik-baiknya. Teori belajar ini berusaha memahami perilaku belajar berasal dari sudut pandang pelakunya, bukan menurut sudut pandang pengamatnya. Aplikasi belajar menurut teori Humanistik yaitu menekankan pentingnya isi dari proses belajar yang bersifat eklektik, yang tujuannya memanusiakan manusia atau mencapai aktualisasi diri. Aplikasi teori Humanistik pada pembelajaran dosen lebih mengarahkan mahasiswa agar berpikir induktif, mementingkan pengalaman, dan membutuhkan keterlibatan mahasiswa secara aktif pada proses belajar. Proses belajar ini dapat diterapkan melalui kegiatan diskusi, membahas materi secara berkelompok sehingga mahasiswa dapat mengemukakan pendapatnya masing-masing.

Dosen memberi kesempatan kepada mahasiswanya untuk bertanya apabila dirasa kurang paham terhadap materi yang disampaikan. Indikator dari keberhasilan aplikasi ini adalah mahasiswa merasa senang bergairah, berinisiatif dalam belajar dan terjadi perubahan pola pikir, perilaku dan sikap atas kehendaknya sendiri.

Teori belajar humanistik memandang bahwa belajar dipengaruhi oleh bagaimana manusia berpikir dan bertindak, bagaimana manusia dipengaruhi dan diarahkan oleh arti pribadi dan perasaan-perasaan yang mereka ambil dari pengalaman belajar mereka sendiri. ${ }^{13}$ Dalam pelaksanaannya, teori humanistik sangat mementingkan isi dari apa yang telah dipelajarinya dari pada proses belajar itu sendiri. Teori belajar ini lebih banyak berbicara mengenai konsep-konsep pendidikan untuk membentuk manusia yang dicita-citakan, serta tentang proses belajar dalam bentuknya yang paling sempurna. Teori ini beranggapan bahwasanya teori belajar apapun itu dapat dimanfaatkan dengan tujuan memanusiakan manusia yaitu dengan mencapai aktualisasi diri, pemahaman diri secara optimal. Teori humanistik juga memandang faktor motivasi dan pengalaman emosional dalam proses belajar sangat penting. Tanpa faktor motivasi tersebut maka proses pembelajaran tidak dapat dilakukan secara maksimal.

${ }^{13}$ Psikologi Pendidikan. h. 181 
Pendidikan humanistik bukanlah sebuah strategi belajar, namun sebagai sebuah filosofi belajar yang sangat memperhatikan keunikan-keunikan yang dimiliki oleh setiap individu, dimana setiap individu memiliki cara sendiri dalam mengolah pengetahuan yang telah dipelajarinya.

Adapun salah satu tokoh dalam teori belajar humanistik adalah Carl Rogers. Carl Ransom Rogers (1902-1987) lahir di Oak Park, Illinois pada tanggal 8 Januari 1902 disebuah keluarga Protestan yang fundamentalis. Rogers merupakan tokoh humanistis dalam teori-teori balajar dari psikologi humanistik. Perhatian psikologi humanistik tertuju pada setiap permasalahan bagaimana setiap individu dipengaruhi dan dibimbing oleh maksud-maksud pribadi yang mereka hubungkan kepada pengalaman-pengalaman mereka sendiri.

Rogers adalah seorang psikolog humanistik yang gagasan-gagasannya berpengaruh terhadap pikiran dan praktek pendidikan. Lewat karya-karyanya yang tersohor seperti "Freedom to learn and Freedom to learn for the 80's" dia menyarankan suatu pendekatan pendidikan yang berupaya menjadikan belajar dan mengajar lebih manusiawi dan dan dipenuhi dengan makna.

Rogers kurang menaruh perhatian kepada mekanisme proses belajar. Belajar dipandang sebagai fungsi keseluruhan pribadi. Mereka berpendapat bahwa belajar yang sebenarnya tidak dapat berlangsung bila tidak ada keterlibatan intelektual maupun emosional peserta didik. Oleh karena itu, menurut teori belajar humanistik bahwa motivasi belajar harus bersumber pada diri peserta didik itu sendiri.

Ada dua tipe belajar yaitu belajar yang bermakna dan belajar yang tidak bermakna. Belajar yang bermakna terjadi jika dalam proses pembelajaran melibatkan aspek pikiran dan perasaan mahasiswa. Sedangkan, pembelajaran yang tidak bermakna terjadi apabila dalam proses pembelajaran tersebut melibatkan aspek pikiran akan tetapi tidak melibatkan aspek perasaan dari mahasiswa. ${ }^{14}$

Ciri-ciri belajar humanistik yang diidentifikasikan sebagai sentral dari filsafat pendidikannya, yaitu $:^{15}$

\footnotetext{
${ }^{14}$ Jamil Suprihatiningrum, Strategi Pembelajaran: Teori Dan Aplikasi (Yogyakarta: Ar-Ruzz Media, 2013). h. 31 - 32 15 Psikologi Pendidikan. h. 183 - 187
} 
a. Hasrat untuk belajar

Menurut Rogers manusia itu mempunyai hasrat alamiah untuk belajar. Hal ini dibuktikan dengan rasa ingin tahunya jika dia sedang mengeksplorasi lingkungannya. Dorongan ingin tahu dalam belajar ini merupakan asumsi dasar pendidikan humanistik. Di dalam kelas yang humanistik mahasiswa diberi kebebasan untuk memuaskan dorongan keingintahuannya, untuk memenuhi minatnya dan untuk menemukan apa yang penting dan berarti tentang dunia disekelilingnya. Orientasi ini bertentangan sekali dengan kelas-kelas gaya lama dimana pendidik atau kurikulum menentukan apa yang harus dipelajari oleh mahasiswa.

b. Belajar yang berarti

Prinsip kedua ini adalah belajar yang berarti, yang mempunyai makna. Hal ini terjadi apabila yang dipelajari relevan dengan kebutuhan dan maksud mahasiswa. mahasiswa akan belajar dengan cepat apabila yang dipelajari itu sangat berarti baginya.

c. Belajar tanpa ancaman

Belajar itu mudah dilakukan dan hasilnya dapat disimpan dengan baik apabila berlangsung dalam lingkungan yang bebas ancaman. Proses belajar berjalan dengan lancar apabila mahasiswa dapat menguji kemampuannya, dapat mencoba pengalaman-pengalaman baru atau membuat kesalahan-kesalahan tanpa mendapat kecaman yang dapat menyinggung perasaannya.

d. Belajar atas inisiatif sendiri

Bagi para humanis, belajar itu paling bermakna apabila hal itu dilakukan atas inisiatif sendiri dan apabila melibatkan perasaan dan pikiran mahasiswa. Tidak perlu diragukan bahwa menguasai bahan pelajaran itu penting tetapi tidak lebih penting daripada memperoleh kecakapan untuk mencari dan menemukan sumber, merumuskan masalah, menguji praduga dan mengevaluasi.

e. Belajar dari perubahan

Perubahan merupakan fakta hidup yang sentral. Ilmu pengetahuan dan teknologi selalu melaju sangat cepat. Apa yang dipelajari dimasa lalu tidak lagi 
dapat menjadi bekal orang untuk hidup dan berfungsi dengan berhasil didunia ini. Apa yang dibutuhkan sekarang ini adalah orang-orang yang mampu belajar dilingkungan yang sedang berubah dan akan terus berubah seiring berjalannya waktu.

Sedangkan dalam pengaplikasiannya, teori belajar humanistik menurut Roger dibagi menjadi tiga macam program, yaitu $:^{16}$

a. Confluent Education

Confluent Education adalah proses pendidikan yang memadukan antara pengalaman afektif dengan belajar kognitif di suatu forum. Hal ini merupakan cara yang sangat tepat untuk melibatkan mahasiswa secara pribadi ke dalam bahan pelajaran. Dalam pembelajaran ini mahasiswa tidak hanya memperhatikan ataupun membaca, tetapi mahasiswa juga dapat merasakan, menuliskan, menghayati, berdebat yang positif, dan menyampaikan pendapat mereka.

\section{b. Open Education}

Open Education adalah proses pendidikan yang terbuka. Dalam pendidikan terbuka ini mahasiswa diberikan kesempatan untuk bergerak secara bebas di lingkungan sekitar dan memilih aktifitas belajar mereka sendiri, namun tetap diberi bimbingan. Salah satu ciri yang menonjol adalah lingkungan fisik ruang kelas dimana mahasiswa belajar secara individual maupun kelompok. Sebagian besar pengajaran individual dilengkapi dengan pusat-pusat kegiatan didalam kelas yang memungkinkan mahasiswa mengeksplorasi bidang-bidang pelajaran, topik-topik, keterampilan maupun minat tertentu.

\section{c. Cooperative Learning}

Pembelajaran cooperative learning mengacu pada metode pembelajaran dimana mahasiswa bekerjasama dan saling membantu dalam belajar. Pada metode ini, setiap anggota kelompok bertanggung jawab atas ketuntasan atas tugas-tugas kelompok dan mempelajari materinya sendiri-sendiri.

Untuk mengetahui terimplementasikannya teori humanistik dalam pembelajaran, maka perlu adanya suatu indikator. Menurut Rogers, terdapat beberapa ciri-ciri pembelajran humanistik, antara lain :

${ }^{16}$ Sri Rumini and dkk, Psikologi Pendidikan (Yogyakarta: UPP IKIP Yogyakarta, 1993). H. 110116 
a. Keinginan untuk belajar

1) Pembelajaran yang berpusat pada peserta didik

2) Pendidik bertindak sebagai fasilitator

3) Pendidik memberi kebebasan kepada peserta didik untuk mencari informasi dari berbagai sumber

4) Peserta didik antusias mengikuti proses pembelajaran

b. Belajar tanpa ancaman

1) Pendidik melibatkan perasaan dan pikiran peserta didik dalam pembelajaran

2) Pendidik menghargai potensi yang dimilikki peserta didik

3) Pendidik toleran terhadap kesalahan yang dilakukan peserta didik selama kegiatan pembelajaran berlangsung

c. Belajar atas inisiatif sendiri

1) Pembelajaran melibatkan peserta didik seutuhnya

2) Peserta didik aktif dalam proses pembelajaran

3) Peserta didik memiliki rasa tanggung jawab dan percaya diri selama proses pembelajaran berlangsung

\section{Pembelajaran Konsep Dasar Sains}

Belajar dan pembelajaran merupakan istilah yang tidak terpisahkan. Setiap ada pembelajaran pasti di dalamnya ada belajar. Pembelajaran secara sederhana dapat diartikan sebagai sebuah usaha yang dapat mempengaruhi emosi, intelektual, dan spiritual seseorang supaya tergerak mau belajar dengan kehendaknya sendiri. Melalui pembelajaran akan terjadi proses pengembangan moral keagamaan, aktivitas, dan kreativitas peserta didik melalui berbagai interaksi dan pengalaman belajar. ${ }^{17}$ Pembelajaran akan lebih bermakna, apabila mahasiswa ikut mengalami, merasakan dan melaksanakan proses belajar itu sendiri.

Konsep dasar sains merupakan bagian dari mata kuliah yang diberikan di sebuah perguruan tinggi fakultas pendidikan khususnya program studi Pendidikan Guru Madrasah Ibtidaiyah. Konsep dasar sains adalah suatu ilmu terapan dasar yang mencari akar permasalahan dari teknologi yang berkembang saat ini, misalnya adalah kemagnetan, kelistrikan, ciri-ciri makhluk hidup, sistem

${ }^{17}$ Abuddin Nata, Perspektif Islam Tentang Strategi Pembelajaran (Jakarta: Kencana, 2009). h. 85 
organ tubuh manusia, dll yang terangkum dalam suatu ilmu aplikatif. Konsep dasar sains ini merupakan cikal bakal sains dan teknologi itu berkembang. Dalam hal ini Sains sendiri merupakan sebuah usaha manusia dalam memahami alam semesta melalui pengamatan yang tepat (correct) pada sasaran, serta menggunakan prosedur yang benar (true), dan dapat dijelaskan dengan penalaran yang tepat (valid) sehingga dihasilkan kesimpulan yang sesuai/benar (truth). IPA / Sains mengandung tiga hal diantaranya yaitu:

a. IPA sebagai proses, yaitu usaha manusia dalam memahami alam smesta

b. IPA sebagai prosedur, dimana pengamatan yang tepat dan prosedurnya harus benar.

c. IPA sebagai produk, kesimpulan yang diambil harus benar.

Pembelajaran Konsep Dasar Sains merupakan upaya dosen dalam menyampaikan pembelajaran kepada mahasiswa melalui penerapan berbagai metode pembelajaran yang dipandang sesuai dengan karakteristik mahasiswanya.

Adapun ruang lingkup bahan kajian konsep dasar sains meliputi aspekaspek sebagai berikut :

a. Besaran dan satuan

b. Materi, meliputi sifat materi, pengelompokan materi, dan perubahan materi.

c. Gerak dan energi, meliputi gerak benda, konsep energi mekanik, dan pesawat sederhana.

d. Suhu dan energi panas, meliputi suhu dan pemuaian serta perubahan wujud benda.

e. Energi bunyi, meliputi getaran, perambatan bunyi, dan pemantulan serta penyerapan bunyi.

f. Energi cahaya, meliputi sifat-sifat cahaya, penggabungan dan pisahan warna, serta mata.

g. Listrik sederhana, meliputi konsep dan resistansi listrik, rangkaian terbuka dan tertutup, serta rangkaian seri dan pararel.

h. Kemagnetan, meliputi magnet dan benda yang ditarik oleh 50 menit magnet, medan magnet dan kutub-kutub magnet. 
i. Ciri-ciri makhluk hidup, meliputi faktor pertumbuhan dan perkembangbiakan.

j. Tumbuhan dan lingkungannya, meliputi bagian tumbuhan dan fungsinya, biji, reproduksi vegetatif, dan habitat tumbuhan.

k. Hewan dan lingkungannya, meliputi pengelompokan hewan.

1. Fotosintesis pada tumbuhan, meliputi factor yang mempengaruhi fotosintesis dan proses fotosintesis,

m. Anatomi dan fiologi tubuh manusia, meliputi sistem rangka dan otot, sistem syaraf, sistem transportasi dan respirasi, sistem pencernaan dan nutrisi.

n. Benda-benda langit, meliputi bumi, sistem bumi, bulan dan matahari serta sistem tata surya.

Dari uraian di atas dapat ditarik kesimpulan bahwa pembelajaran konsep dasar sains lebih kepada proses mengembangkan keterampilan untuk menyelidiki alam sekitar, memecahkan masalah dan membuat berbagai keputusan. Pembelajaran konsep dasar sains harus berpusat pada mahasiswa serta memberi kesempatan kepada mahasiswa untuk mengembangkan suatu ide maupun gagasan, berdiskusi satu sama lain serta membandingkan ide mereka dengan konsep ilmiah berupa hasil pengamatan dan percobaan yang pada akhirnya mahasiswa dapat menemukan sendiri apa yang telah mereka pelajari. Hal ini cukup berpengaruh untuk peningkatkan pemahaman mahasiswa pada pembelajaran konsep dasar sains. 


\section{Implementasi Teori Belajar Humanistik pada Materi Bagian Tumbuhan dan Fungsinya}

Dalam prakteknya teori humanistik cenderung mengarahkan mahasiswa untuk dapat berfikir induktif, mementingkan pengalaman, dan membutuhkan keterlibatan mahasiswa secara aktif didalam proses pembelajaran.

Dalam pembelajaran konsep dasar sains tentang bagian tumbuhan dan fungsinya, seorang dosen hendaknya tidak memberikan materi dengan metode ceramah. Akan lebih baik apabila dosen benar-benar menghadirkan berbagai macam tumbuhan yang nantinya dijadikan sebagai bahan yang akan didiskusikan oleh mahasiswa di kelas. Namun apabila disekitar lingkungan terdapat kebun yang ditumbuhi berbagai macam jenis tumbuhan, maka mahasiswa dapat diajak untuk mengamati tumbuhan di kebun tersebut secara langsung. Terlebih jika didalam kebun yang ada dilingkungan sekolah tersebut ditumbuhi oleh TOGA (tanaman obat dan keluarga). Jadi, selain menjelaskan bagian-bagian tumbuhan secara langsung, mahasiswa juga bisa mengenal dan mengetahui tumbuhan yang memiliki manfaat sebagai obat. Hal ini tentu menjadikan pembelajaran menjadi lebih menarik. mahasiswa akan mengetahui bahwa tumbuhan yang sedang ia pelajari ternyata juga dapat ia manfaatkan sebagai obat didalam kehidupan sehari-harinya.

Adapun langkah-langkah implementasi teori humanistik pada materi bagian tumbuhan dan fungsinya sebagai berikut :

a. Menentukan tujuan-tujuan pembelajaran. Pada materi bagian tumbuhan dan fungsinya, mahasiswa diharapkan mampu menjelaskan konsepkonsep dari bagian-bagian tumbuhan beserta fungsi dari bagian-bagian tumbuhan itu sendiri.

b. Menentukan materi-materi pembelajaran. Materi yang disampaikan terdiri dari bagian tumbuhan yakni akar, batang, daun, bunga, buah dan biji. Selain itu juga dijelaskan apa saja fungsi dari bagia-bagian tumbuhan tersebut.

c. Mengidentifikasi kemampuan awal dari mahasiswa. Kemampuan awal mahasiswa adalah kemampuan yang telah dipunyai oleh mahasiswa sebelum ia mengikuti pembelajaran yang akan disampaikan. Kemampuan awal (entry behavior) ini menggambarkan 
kesiapan mahasiswa dalam menerima penjelasan materi yang akan disampaikan oleh dosen.

d. Mengidentifikasi topik-topik bahasan yang memungkinkan akan melibatkan mahasiswa untuk dapat belajar secara aktif. Disetiap poinpoin penjelasan mengenai bagian tumbuhan dan fungsinya, seorang dosen dapat melibatkan mahasiswanya dengan pertanyaan-pertanyaan singkat yang nantinya akan menggerakkan kemampuan mahasiswa untuk berfikir dan belajar secara aktif.

e. Merancang fasilitas belajar, seperti lingkungan dan media-media yang akan digunakan. Pada poin ini, dosen bisa menggunakan media tumbuhan asli supaya mahasiswa dapat langsung mengamati secara nyata. Selain itu juga bias menggunakan media power point yang nantinya dapata ditampilkan di layar, sehingga mahasiswa juga bisa mendeskripsikan mengenai bagian tumbuhan dan fungsinya.

f. Membimbing mahasiswa agar bertanggung jawab atas perbuatan yang dilakukan selama prosem pembelajaran.

g. Membimbing mahasiswa agar peka dan berpikir kritis dengan memaknai proses pembelajaran secara mandiri

h. Membimbing mahasiswa dalam mengaplikasikan pengalaman belajarnya kedalam situasi yang nyata.

i. Mengevaluasi proses dan hasil belajar.

Selain itu sebagai seorang dosen harus memahami betul bahwa peran dosen pada teori humanistik hanya sebagai fasilitator. Untuk menerapkan teori pembelajaran ini, tugas fasilitator adalah sebagai berikut :

a. Memperhatikan dan memberikan motivasi belajar pada para mahasiswa

b. Jika mahasiswa belum memahami sepenuhnya mengenai tujuan pembelajarannya, dosen bisa memberikan penjelasan kembali

c. Seorang dosen harus bisa memahami karakter setiap mahasiswanya

d. Menyediakan sumber belajar, baik buku, media visual, maupun audio

e. Tetap menjalin komunikasi dengan mahasiswa agar kondisi pembelajaran tetap terkontrol 
f. Selalu memberikan dorongan pada mahasiswa agar lebih peka dan kreatif

g. Mengondisikan suasana belajar agar tetap kondusif

h. Memacu keaktifan mahasiswa

Sementara itu dalam pembelajaran konsep dasar sains berparadigma humanistik, seorang dosen dapat menggunakan strategi dan metode pembelajaran aktif, kreatif dan menyenangkan. Pembelajaran aktif dimaksudkan bahwa dalam proses pembelajaran, dosen harus menciptakan suasana sedemikian rupa sehingga mahasiswa aktif bertanya, mempertanyakan, dan mengemukakan gagasan. Misalnya dalam materi pembelajaran bagian tumbuhan dan fungsinya, seorang dosen bisa memperlihatkan bagian-bagian tumbuhan secara langsung untuk memberikan kesempatan dan rangsangan agar mahasiswa bertanya, mempertanyakan tumbuhan dapat beridiri karena tersusun dari apa saja dan apa fungsi dari masing-masing bagian tumbuhan tersebut.

Pembelajaran kreatif adalah sistem pembelajaran yang menstimulasi mahasiswa untuk mengembangkan gagasannya dengan memanfaatkan sumber belajar yang ada. Pembelajaran kreatif menekankan pada pengembangan kreatifitas, baik pengembangan kemampuan imajinasi maupun pengembangan kemampuan berpikir kreatif. Pembelajaran kreatif dalam konsep dasar sains, misalnya seorang dosen membimbing mahasiswa untuk memahami bagian tumbuhan beserta fungsinya, memahami bagaimana jika tumbuhan tersebut tidak memiliki bunga atau buah, apa yang akan terjadi.

Sementara itu, pembelajaran yang menyenangkan (joyful) adalah pembelajaran yang dapat dinikmati mahasiswa. Mahasiswa merasa nyaman, aman dan asyik. Perasaan yang mengasyikkan mengandung unsur inner motivation, yaitu dorongan keingintahuan yang disertai upaya mencari tahu sesuatu. Penggunaan strategi tesebut dimaksudkan agar siswa dapat terlibat aktif, menggunakan daya kreativitas, melaksanakan pembelajaran konsep dasar sains dengan tanpa tertekan apalagi terancam. 


\section{Kesimpulan dan Saran}

\section{Kesimpulan}

Berdasarkan penjelasan dari pembahasan diatas implementasi teori belajar humanistik dapat dilihat dalam kegiatan pembelajaran melalui langkah-langkah pembelajaran humanistik, yaitu yang pertama menentukan tujuan pembelajaran, kedua menentukan materi pembelajaran, ketiga mengidentifikasi kemampuan awal mahasiswa, keempat mengidentifikasi topik bahasan, kelima merancang fasilitas belajar, keenam membimbing mahasiswa agar bertanggung jawab atas perbuatan yang dilakukan selama proses pembelajaran, ketujuh membimbing mahasiswa agar peka dan berpikir kritis dengan memaknai proses pembelajaran secara mandiri, kedelapan membimbing mahasiswa dalam mengaplikasikan pengalaman belajarnya kedalam situasi yang nyata, dan yang terakhir mengevaluasi proses ddan hasil belajar.

Dalam teori humanistik ini mahasiswa belajar tidak hanya dengan mendengar penjelasan dari dosen, akan tetapi juga dengan melihat, menyentuh, merasakan dan mengikuti keseluruhan proses dari setiap pembelajaran, sehingga belajar menjadi lebih berkesan. Mahasiswa diarahkan untuk belajar secara aktif dan tidak hanya dituntut belajar dari buku, namun juga dapat menggali pengetahuan dari alam sekitarnya. Posisi dosen dalam hal ini hanya sebagai fasilitator, motivator, dan stimulator. Dalam pembelajaran konsep dasar sains ini dosen dapat menanamkan sikap dan kepribadian mahasiswa untuk mencintai lingkungan sekitarnya serta pembiasaan mahasiswa untuk selalu merawat lingkungan sekitarnya.

\section{Saran}

Dengan adanya teori belajar humanistik diharapkan mahasiswa lebih meningkatkan keaktifannya sehingga pembelajaran dapat membentuk mahasiswa seutuhnya.

Dosen tetap menerapkan pembelajaran yang berpusat pada mahasiswa dan mneingkatkan pemahaman terhadap mahasiswa terkait dengan potensi yang dimiliki. 


\section{Daftar Pustaka}

Baharuddin, and Moh. Makin. Pendidikan Humanistik: Konsep, Teori Dan Aplikasi Praksis Dalam Dunia Pendidikan. Yogyakarta: Ar-Ruzz Media, 2007.

Dra. Tutik Rachmawati, M.Pd. Teori Belajar Dan Proses Pembelajaran Yang Mendidik. Yogyakarta: GAVA MEDIA, 2015.

El Rais, Heppi. Kamus Ilmiah Populer. Yogyakarta: Pustaka Pelajar, 2012.

Nata, Abuddin. Perspektif Islam Tentang Strategi Pembelajaran. Jakarta: Kencana, 2009.

Rumini, Sri, and dkk. Psikologi Pendidikan. Yogyakarta: UPP IKIP Yogyakarta, 1993.

Siregar, Eveline, and Hartini Nara. Teori Belajar Dan Peembelajaran. Bogor: Ghalia Indonesia, 2011.

Sri Esti Wuryani Djiwandono. Psikologi Pendidikan. Jakarta: Grasindo, 2006.

Suprihatiningrum, Jamil. Strategi Pembelajaran: Teori Dan Aplikasi. Yogyakarta: Ar-Ruzz Media, 2013.

Suprijono, Agus. Cooperative Learning Teori Dan Aplikasi Paikem. Yogyakarta: Pustaka Pelajar, 2011.

Susilo, M. Joko. Kurikulum Tingkat Satuan Pendidikan. Yogyakarta: Pustaka Pelajar, 2007.

Syah, Muhibbin. Psikologi Pendidikan: Suatu Pendekatan Baru. Bandung: Remaja Rosdakarya, 1995.

Winkel, W.S. Psikologi Pengajaran. Yogyakarta: Media Abadi, 2004.

Zaenul Fitri, Agus. Manajemen Kurikulum Pendidikan Islam. Bandung: ALVABETA cv, 2013. 